\title{
Food Consumption as a Risk Factor of Anemia among Indonesian Pregnant Women: A Cross-sectional Study among Javanese Ethnic Group
}

\author{
Mekar Dwi Anggraeni ${ }^{1 *(D)}$, Amin Fatoni ${ }^{2}$ D, Rahmi Setiyani ${ }^{1}$ D \\ ${ }^{1}$ Department of Nursing, Faculty of Health Sciences, Universitas Jenderal Soedirman, Purwokerto, Indonesia; ${ }^{2}$ Department of \\ Chemistry, Faculty of Mathematics and Natural Sciences, Universitas Jenderal Soedirman, Purwokerto, Indonesia
}

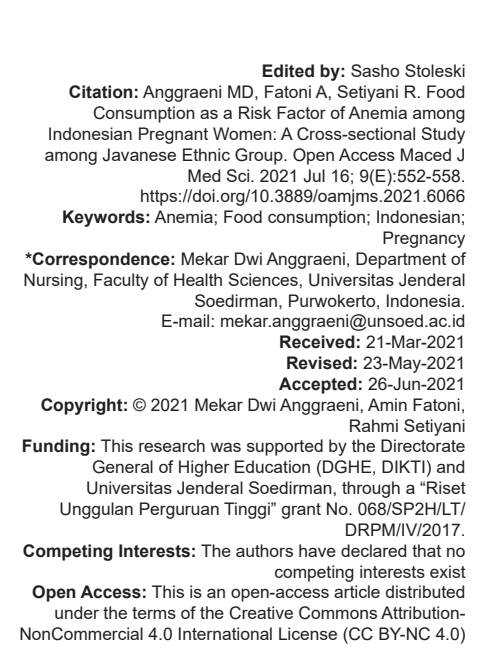

\begin{abstract}
BACKGROUND: Anemia during pregnancy causes several adverse effects. Furthermore, in Indonesia, this leads to restrictions among pregnant women. The information on this situation is still limited, and more research needs to be conducted.

AIM: Therefore, this study aims to investigate the association between food consumption and anemia among pregnant women.

METHODS: This is a cross-sectional descriptive research that involved 424 pregnant women. Furthermore, written informed consent was obtained from respondents before data collection. A self-administered questionnaire was used to assess the food consumption and demographic data. Hemoglobin concentration was further measured using a haemoglobinometer, and data were analyzed using a descriptive statistical Chi-square, and a Multiple Logistic Regression test.

RESULTS: It was found that half of the respondents suffered from anemia (46.5\%). Furthermore, the Multiple Logistic Regression test showed that tea, liver, eggs, and iron consumption with values of (odds ratio [OR] $=5.075$, $p<0.001),(O R=4.128, p<0.001),(O R=3.590, p<0.01)$, and $(O R=3.837, p<0.05)$, respectively, had significant correlations with anemia among pregnant women.

CONCLUSIONS: Anemia is commonly experienced by Indonesian pregnant women. Therefore, health-care providers should focus on preventing anemia in pregnant women by reducing their tea intake and increasing the consumption of iron-rich foods or supplements.
\end{abstract}

\section{Introduction}

Maternal mortality rate $(M M R)$ is an important indicator when describing a country's social welfare [1]. Furthermore, Indonesia has one of the high MMR among countries in the Asia region [2]. In this country Indonesian Demographic and Health Survey that MMR in the country was 177 per 100,000 live births [3]. According to data from the Ministry of Health, antenatal bleeding was the major cause of maternal mortality in 2019. Furthermore, one-third $(30.3 \%)$ of Indonesian women die from bleeding during pregnancy processes, childbirth, and postpartum [1].

The risk factors that cause bleeding during childbirth are high maternal age, parity $<3$, poor birth history, prolonged labor, and anemia [4]. Anemia during pregnancy has a significant relationship with maternal death in low- and middle-income countries [5]. Studies show that there was a significant relationship between anemia during pregnancy and postpartum hemorrhage in Indonesia [6], [7].
In addition, women who experiencing postpartum hemorrhage had a history of suffering from anemia during pregnancy [8].

Anemia during pregnancy is a major health problem. Consequently, data from the Indonesian Basic Health Research showed that the prevalence of anemia among pregnant women in the country increased significantly from $37.1 \%$ in 2013 to $48.9 \%$ in 2018 [9]. This means that almost half of pregnant women currently suffer from this disease. Therefore, investigating factors that cause anemia in pregnant women is very important.

Anemia during pregnancy is also associated with several factors, such as drinking more than three cups of tea per day before pregnancy, ingestion of clay or dirt during pregnancy, reduced egg intake, consuming less beef [10], meal frequency, dietary diversity, and parity [11]. Tea contains tannin, which is well known as an iron absorption inhibitor, therefore, consuming tea after meals causes a $60 \%$ decrease in iron uptake [12]. Furthermore, serum iron and ferritin are significantly 
higher in non-tea drinkers compared to tea drinkers [13]. $A$ research showed that the major cause of anemia during pregnancy in Indonesia is iron deficiency [14]. Consequently, humans obtain iron from food because their bodies do not produce it [15]. Studies about the adverse effects of food consumption on pregnancy were mostly conducted in Western [16], [17], [18], [19], [20] and other Asian countries [21], [22]. Therefore, there is few information on the correlation between food consumption and anemia among Javanese pregnant women in Indonesia.

Cultural beliefs during pregnancy contribute to pregnant women's choice of food. This is because, Javanese people have a strong belief that eating foods such as beef, eggs, and fish is a taboo. However, these are foods rich in protein and iron which influence pregnant women's hemoglobin concentration [23]. Another Javanese culture is drinking tea during meals, which causes a decrease in the absorption of non-heme iron, thereby leading to iron deficiency anemia [24], [25]. A randomized control study showed that drinking tea with meals decreases iron absorption. However, taking it after meals reduces the inhibitory effect on iron absorption [26]. Furthermore, components of beverages such as tea, directly affect iron bioavailability and inhibit iron absorption [27]. A recent study showed that the cultural beliefs of Javanese people are changing, particularly among the young generation [28]. Therefore, in order to prevent anemia in pregnant women, it is essential to examine the association between food consumption and this disease.

Studies aimed at determining the predictors of anemia during pregnancy have been conducted in Indonesia [14], [29]. However, they only examined the correlation between infectious diseases and the sociodemographic factors of anemia. Studies on anemia in pregnant women need to be updated. According to the Indonesian Ministry of Health's report in 2018, the Central Java Province had a high prevalence of anemia among pregnant women and teenagers. Therefore, this study aimed to determine predictors of anemia among pregnant women in the Central Java Province.

\section{Methods}

\section{Research design and participants}

This study used a descriptive cross-sectional design, which was conducted in the Central Java Province among Javanese people, the largest ethnic group [30], on the most populous island in Indonesia. The Yamane's formula was used to calculate the subject of research $n=\frac{N}{1+N(e)^{2}}$ [31]. The population of pregnant women (n) was 29,464 [32], with a precision of 0.05 . Furthermore, the research used $10 \%$ of this number as the respondents. Therefore, the required the subjects in this research were 424 respondents.

The research involved 424 respondents which were selected using a random multistage cluster sampling to obtain subjects that represent pregnant women from both rural/urban areas, sub-districts, and health care facilities [33]. These subjects were recruited from 3 antenatal care clinics at the hospital and 7 Primary Health Centres which were selected randomly from 17 hospitals and 39 Primary Health Centres. Furthermore, in each health care facility, pregnant women were categorized into three groups according to their trimester, after which some were randomly selected.

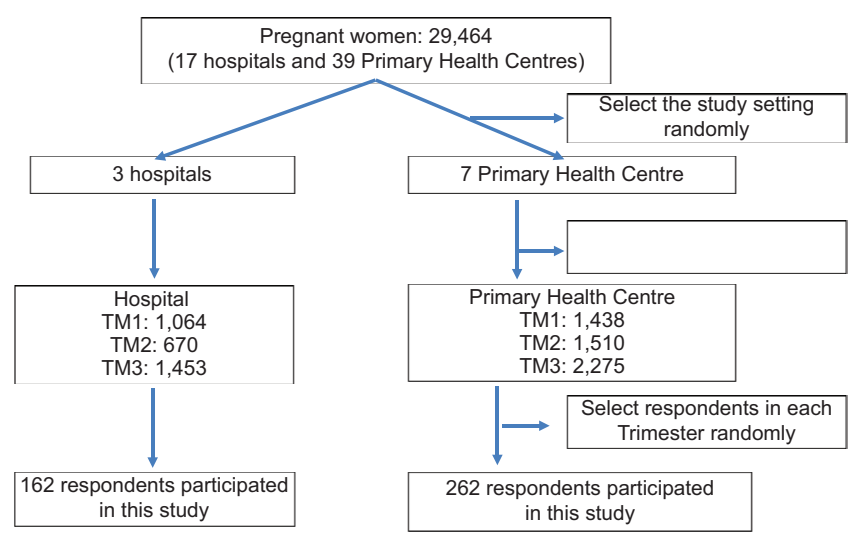

The inclusion criteria of respondents were pregnant women with 4-38 weeks of gestation, routine antenatal care visits, and willingness to participate in this research. Meanwhile, the exclusion criteria included a history of chronic bleeding, thalassemia, malaria, and chronic diseases such as inflammatory bowel movement, autoimmune diseases, cancer, chronic infections and renal failure, solid tumors, and chronic heart failure [34].

Data was collected using a set of questionnaires and a hemoglobinometer. Sociodemographic data were obtained using a self-developed questionnaire based on literature review, and included questions such as maternal and gestational age, parity, education concentration, working status, family income, and abortion history. Data on food consumption were collected using a set of questionnaires and hemoglobin concentrations were measured using a hemoglobinometer.

\section{Data collection}

Data were collected from February 2018 to June 2018 by four research assistants with bachelor degrees in Nursing Science. There was a discussion on the purpose, ethics, informed consent, and data collection methods. Data collection only started after receiving the ethical approval and permit from the Indonesian Ministry of Health and Government office 
and providing information to respondents related to the research purpose, benefits, procedures, and required time. The respondent was willing to participate in this research signed in a written consent form to show that they understood the research information and had agreed to participate.

\section{Dietary analysis}

The variables needed in this research were the frequency of (times/week) red beef, eggs, liver, tea, milk consumption, and the current hemoglobin level. The items such as eggs, beef, liver, and milk were chosen because of their high consumption prevalence among Javanese and their high Fe content. Tea was also chosen because it is a popular beverage and it is usually drinking after meals even though tea inhibits the absorption of $\mathrm{Fe}$ in the small intestine. The food consumption frequency questionnaire (FCFQ) and dietary history questionnaire (DHQ) were examined for content validity, language, and cultural suitability by a panel of three experts consisting two faculty members from the Department of Nutrition, Universitas Jenderal Soedirman and a faculty member from Department of Nursing, Universitas Jenderal Soedirman. Then, the reliabilities of instruments were performed with 25 pregnant women. All details of Content Validity Indices (CVI) and reliabilities were explained in each scale.

The back-translation process was performed based on Hilton and Skrutkowski guidelines (2002). The original questionnaires were translated from English into Bahasa Indonesian version. Next, the questionnaires were translated back from Bahasa Indonesian version into the English version. The process was carried out by three bilingual lecturers in Health Sciences with master's degrees from countries where English is the main language. Last, a native English speaker evaluated the original and backtranslated questionnaires.

The data on the frequency of beef, liver, and eggs consumptions was collected using a FCFQ developed by Zhao et al. (2014). These frequency data were categorized into (1) never or less than once per week, (2) once to 6 times per week, and (3) daily [35]. The categorization is also in accordance with the Indonesian nutrition guidelines [36]. Meanwhile, data was validated with 24-h recall of foods eaten the day before the survey. The CVI of the questionnaire was 0.97 and reliability testing using a Pearson correlation was 1.

Furthermore, data on the frequency of milk and tea consumption was collected using a DHQ created by Okubo et al. (1998). The frequency of milk intake was categorized into (1) never or less than a cup per week, (2) once to six cups per week, and (3) daily. Meanwhile, that of tea consumption was categorized into (1) 0-1 cup per day, (2) 2-3 per day, (3) 4-5 daily, and (4) $\geq 6$ cups daily [21].
This categorization is also in accordance with the Indonesian nutrition guidelines [36]. The data was validated with 24-h recall of foods eaten the day before the survey. The CVI of the questionnaire was 0.98 and reliability testing using a Pearson correlation was 0.99 .

Blood samples were collected from finger pricks, while hemoglobin concentrations were measured using the EasyTouch ${ }^{\circ} \mathrm{GCHb}$ (Bioptik Technology Inc., Taiwan), with a measuring range of $7-26 \mathrm{~g} / \mathrm{dL}$ [37]. The respondents were then categorized into anemia $(<11 \mathrm{~g} / \mathrm{dL})$, and non-anemia $(\geq 11 \mathrm{~g} / \mathrm{dL})$ according to their hemoglobin concentrations. Furthermore, pregnant women with anemia were categorized into mild (9-10.9 g/dL), moderate (7-8.9 g/dL), and severe (<7 g/dL) [38].

\section{Data analysis}

The data were analyzed using descriptive statistics mean, median, and frequency. The Chi-square test was used to analyze the correlation between beef, liver, eggs, iron tablets, tea, milk consumption, and anemia status. Variables with a $p$-value of $>0.25$ were included in a multivariate analysis. Then, Multiple Logistic Regression (with the backward Wald and $95 \% \mathrm{Cl}$ ) was used to obtain odds ratios (ORs) and analyze the predictive factors of anemia. Furthermore, the two-tailed $p$-value of $<0.05$ was used to indicate the significance. The SAS software version 9.4 (SAS Institute Inc., Cary, NC, USA) was used to perform all the statistical analyses.

\section{Results}

\section{Prevalence of anemia}

The overall prevalence of anemia was $46.5 \%$, with $86.29 \%$ and $13.71 \%$ of these anemic respondents having mild and moderate anemia respectively.

\section{Respondents' demographic characteristics}

This research involved 424 respondents, each having characteristics described in Table 1. The mean of respondents' age and gestational ages were $27.42 \pm \mathrm{SD}=5.9$ years and $24.32 \pm$ $\mathrm{SD}=10.04$ weeks, respectively. Most respondents were in their third trimester (44.3\%), multiparous $(72.2 \%)$, and had graduated from Senior High School (39.6\%). They were also housewives $(65.6 \%)$ with a family income of USD 120 (83.3\%). $80.7 \%$ had no abortion history and most had a mean hemoglobin concentration of $10.94 \pm S D=1.89 \mathrm{~g} / \mathrm{dL}$. Most respondents consumed iron supplementation 
Table 1: The research respondents' characteristics $(n=424)$

\begin{tabular}{|c|c|c|}
\hline Characteristics & Frequency & Percentage \\
\hline \multicolumn{3}{|l|}{ Age } \\
\hline$<20$ & 32 & 9.9 \\
\hline $20-35$ & 345 & 79.1 \\
\hline$>35$ & 47 & 11 \\
\hline \multicolumn{3}{|l|}{ Parity } \\
\hline Primipara & 118 & 27.8 \\
\hline Multipara & 306 & 72.2 \\
\hline \multicolumn{3}{|l|}{ Pregnancy trimester } \\
\hline First & 126 & 29.7 \\
\hline Second & 110 & 25.9 \\
\hline Third & 188 & 44.3 \\
\hline \multicolumn{3}{|l|}{ Educational level } \\
\hline Elementary & 70 & 16.5 \\
\hline Junior High School & 83 & 19.6 \\
\hline Senior High School & 168 & 39.6 \\
\hline Diploma & 41 & 9.7 \\
\hline Bachelor & 58 & 13.7 \\
\hline Postgraduate & 4 & 0.9 \\
\hline \multicolumn{3}{|l|}{ Working status } \\
\hline Employee & 146 & 34.4 \\
\hline Housewife & 278 & 65.5 \\
\hline \multicolumn{3}{|l|}{ Family income } \\
\hline <USD 120 & 71 & 16.7 \\
\hline 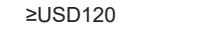 & 353 & 83.3 \\
\hline \multicolumn{3}{|l|}{ Abortion history } \\
\hline Yes & 82 & 19.3 \\
\hline No & 342 & 80.7 \\
\hline \multicolumn{3}{|l|}{$\mathrm{Hb}(\mathrm{g} / \mathrm{dL})$} \\
\hline$<11$ & 197 & 46.5 \\
\hline$\geq 11$ & 227 & 53.5 \\
\hline \multicolumn{3}{|l|}{ Anemia level } \\
\hline Mild & 27 & 13.71 \\
\hline Moderate & 170 & 86.29 \\
\hline \multicolumn{3}{|l|}{ Iron supplementation } \\
\hline Yes & 332 & 78.3 \\
\hline No & 92 & 21.7 \\
\hline \multicolumn{3}{|l|}{ Liver consumption } \\
\hline 0 & 258 & 60.8 \\
\hline $1-6$ & 152 & 39.2 \\
\hline \multicolumn{3}{|l|}{ Beef consumption } \\
\hline 0 & 178 & 42 \\
\hline $1-6$ & 246 & 58 \\
\hline \multicolumn{3}{|l|}{ Eggs consumption } \\
\hline 0 & 41 & 9.7 \\
\hline $1-6$ & 291 & 68.6 \\
\hline$>7$ & 92 & 21.7 \\
\hline \multicolumn{3}{|l|}{ Tea consumption } \\
\hline $0-1$ & 210 & 49.5 \\
\hline $2-3$ & 108 & 25.5 \\
\hline $4-5$ & 88 & 20.8 \\
\hline$\geq 6$ & 18 & 4.2 \\
\hline \multicolumn{3}{|l|}{ Milk Consumption } \\
\hline 0 & 148 & 34.9 \\
\hline $1-6$ & 64 & 15.1 \\
\hline$\geq 7$ & 212 & 50 \\
\hline
\end{tabular}

(78.3\%) and eggs (68.6\%) daily, half drink tea during pregnancy $(50.5 \%)$. While the others not consume liver $(60.8 \%)$ as daily intake.

The Chi-square testing results (Table 2) showed that liver, milk, egg, tea, and iron consumption with values of $\left(\chi^{2}=4.040, p<0.001\right),\left(\chi^{2}=1.255\right.$, $p<0.05),\left(\chi^{2}=4.052, p<0.001\right),\left(\chi^{2}=7.031, p<0.001\right)$, and $\left(\chi^{2}=3.420, p<0.001\right)$ respectively, had significant correlations with anemia risk.

Multiple Logistic Regression and Backward (Wald) testing results (Table 3 ) revealed that pregnant

Table 2: The correlation of beef consumption, milk consumption, liver consumption, eggs consumption, tea consumption, and iron supplementation with anemia among pregnant women ( $n=424)$

\begin{tabular}{lll}
\hline Variables & $\chi^{2}$ & $\mathrm{p}$ \\
\hline Beef consumption & 1.012 & 0.953 \\
Milk consumption & 1.255 & 0.035 \\
Liver consumption & 4.040 & $<0.001$ \\
Eggs consumption & 4.052 & $<0.001$ \\
Tea consumption & 7.031 & 0.008 \\
Iron supplementation & 3.420 & $<0.001$ \\
\hline
\end{tabular}

women with low liver $(\mathrm{OR}=4.128, \mathrm{p}<0.001)$, and eggs consumption $(\mathrm{OR}=3.590, \mathrm{p}<0.01)$, iron supplementation $(\mathrm{OR}=3.837, \mathrm{p}<0.05)$ and higher daily tea consumption $(\mathrm{OR}=5.075, \mathrm{p}<0.001)$ were significantly associated with higher anemia risk after analyzing the respondents' characteristics.

Table 3: The logistic regression for predictors of anemia among pregnant women $(n=424)$

\begin{tabular}{llllll}
\hline Variables & $\mathrm{B}$ & Wald & $\mathrm{OR}$ & $95 \% \mathrm{Cl}$ & $\mathrm{p}$ \\
\hline Liver consumption*** & 1.418 & 34.175 & 4.128 & $2.566-6.640$ & $<0.001$ \\
Eggs consumption** & 1.278 & 8.594 & 3.590 & $1.527-8.437$ & 0.003 \\
Tea consumption*** & 1.624 & 27.831 & 5.075 & $2.776-9.279$ & $<0.001$ \\
Iron supplementation*** & 1.345 & 21.583 & 3.837 & $2.176-6.767$ & $<0.001$ \\
\hline Values presented as odds ratio $\left(95 \%\right.$ of confidence interval), -2 LL $\chi^{2}=459.72$; Hosmer and Lemeshow test \\
( $\left.\chi^{2}\right)=6.33(\mathrm{p}=0.50)$. Cox and Snell $\mathrm{R}^{2}=0.257$ Nagelkerke $\mathrm{R}^{2}=0.34, * \mathrm{p}<0.05,{ }^{* *}<<0.01, * * * \mathrm{p}<0.001$
\end{tabular}

$\left(x^{2}\right)=6.33(p=0.50)$; Cox and Snell $R^{2}=0.257$, Nagelkerke $R^{2}=0.34,{ }^{*} p<0.05,{ }^{* *} p<0.01, * * * p<0.001$

\section{Discussion}

Anemia is a condition where a person's hemoglobin blood concentration is lower normal [39]. This research confirmed that anemia among pregnant women is still high. Furthermore, half of the respondents $(46.5 \%)$ had this condition, with $86.29 \%$ of them having mild anemia, while the remaining $(12.69 \%)$ had moderate. The result is consistent with data from the Indonesian Basic Health Research [9] which showed that $48.9 \%$ of pregnant women aged 25-34 years old were anemic. In this research, pregnant women with low education, multiparous, and low-income families were more likely to become anemic. This is due to lack of anemia prevention knowledge, attitude, and financial problems among families with low education and income.

Intake of iron and protein-rich foods help prevent pregnant women from developing anemia [40]. The result of this study provided consistent data comparing to previous study results on the frequency of iron supplement consumption among pregnant Indonesian women. According to Triharini and Armini (2020), only $52.1 \%$ of pregnant women make use of iron tablets [41]. Previous studies showed that at least half of anemia cases during pregnancy are caused by iron deficiency [42], [43]. Therefore, it was concluded that iron supplementation could prevent anemia among Indonesian pregnant women. Mothers' compliance in consuming iron tablets had a significant effect on anemia within pregnant women [44], [45].

The results show that eating liver during pregnancy correlates with lower anemia risk. Most Indonesian people consume chicken liver and cow liver, which contain 9.2-4.8 mg of iron per $75 \mathrm{~g} \mathrm{(2.5}$ oz), respectively [46]. Eating liver regularly increases hemoglobin concentration and prevents anemia [47]. The anemic status among Japanese is also significantly correlated with the low intake of animal products containing iron, vitamin B-12, and folate [48]. 
A research conducted in Pakistan found that consuming eggs has an effect on hemoglobin concentration among pregnant women [10]. Most Indonesian people also eat eggs in their daily meals because they are cheap, easy to find, and prepare. Furthermore, they consume eggs at the rate of $106.418 \mathrm{~kg} / \mathrm{year}$ [49]. However, the results showed that egg consumption did not prevent anemia among the Indonesian pregnant women, since the egg is considered as a popular food. This is due to the local beliefs among the Javanese which restrict pregnant women from eating foods such as fish and eggs [23].

Those that eat beef as part of their daily diet had higher hemoglobin concentrations when compared to others did not [35]. However, beef consumption did not predict anemia among pregnant women in this research. It was found that only one-third of Indonesian pregnant women eat beef as part of their daily menu [50]. The average beef consumption among Indonesian people is only $0.469 \mathrm{~kg} /$ year [49]. This low intake is due to beef's price which is considered expensive. A research conducted in Japan also found that there was no correlation between beef intake and anemia risk among Japanese people [48].

Milk and tea are well-known as an iron absorption inhibitors. The results showed that milk consumption did not have a significant correlation with anemia among pregnant women. This is because Indonesian people believe sweetened cream to be a dairy product when it is not. In fact, sweetened cream lacks proteins present in milk. This observation was recently made by the Indonesian Food and Drug association [51]. Tea consumption correlated with anemia among pregnant women because they drink it during their meals. Indonesia ranked second in tea consumption among countries in the South East area [52]. Almost half of the Indonesian people, including pregnant women drink tea every day as a habit [50], and a part of their culture even though it is not supported with evidence [28].

In this research, the highest prevalence of anemia was found among pregnant women in the third trimester. According to Ward et al. (2009), these women have the lowest hemoglobin concentration at 30-34 weeks of pregnancy [53]. The results are consistent with others which found that the third trimester of pregnancy was associated with anemia [54], [55].

The scope of this research covered both rural and urban areas and included local beliefs related to food consumption. Meanwhile, its limitations were respondent's recall bias, research assistants, and hemoglobin measurement method. Consequently, future studies should use better hemoglobin measurement methods, recruit nutritionists as a research assistant, and recruit bigger sample sizes.

\section{Conclusions}

This research showed that consumption of iron supplements, iron-rich foods, and tea had significant correlations with anemia among pregnant women. The results suggest that health care providers should consider enhancing the diet of women during pregnancy. This is done by increasing the intake of iron-rich foods and supplements, reducing tea consumption, regular assessment, and intervention at antenatal care. In this cross-sectional study, a relationship was found between risk factors and anemia during pregnancy.

\section{Acknowledgments}

The authors are grateful to the participants of the research, and the health providers for generously providing their experience. The authors also thank Nina Setiawati, Waluyo Sejati, Slamet Turah, and Tuti Hartini for their assistance in data collection.

\section{Authors' Contributions}

MDA: Project design, manuscript writing, data interpretation, project administration, supervision. AF: Data analysis, manuscript writing, review, and editing. RS: Data collection, writing-review, and editing. All authors have read and approved the final manuscript.

\section{Availability of Data and Materials}

The datasets used and/or analysed during this researchare available from the corresponding author on reasonable request.

\section{Ethics Approval and Consent to Participate}

In order to ensure the subjects' human rights, this research obtained an ethical approval from the Institutional Review Board Faculty of Medicine, Universitas Jenderal Soedirman, Indonesia No. 1184/ 
KEPK/III/2018. The authors also received a permit from the Indonesian Ministry of Health and Government office to conduct this research. They have also provided sufficient information related to the research such as purpose, benefits, procedures, potential risks, required time, anonymity, confidentiality, the subjects' rights to withdraw themselves from this research anytime, and the authors' phone numbers for further questions related to this research if needed. The respondents signed a written consent after stating that they understood the purpose, benefits, potential risks, required time, and procedures were willing to participate. The authors have saved the data using codes, and only them have to access this data.

\section{References}

1. Indonesian Ministry of Health. Profil Kesehatan Indonesia Tahun 2019. Jakarta, Indonesia: Indonesian Ministry of Health; 2019. https://doi.org/351.770.212 Ind P

2. UNFPA. Maternal Mortality in Asia-Pacific-5 Key Facts. United States: UNFPA; 2018.

3. UNICEF. Maternal Mortality Declined by 38 Per Cent Between 2000 and 2017. Matern Mortal. Available from: https://www.Data Unicef Org/Topic/Maternal-Health/Maternalmortalityn.d. [Last accessed on 2020 May 25].

4. Dina D. Faktor Determinan Kejadian Perdarahan Post Partum di RSUD Majene Kabupaten Majene. Indonesia: STIKES Bangsa Majene; 2013.

5. Daru J, Zamora J, Fernández-Félix BM, Vogel J, Oladapo OT, Morisaki $\mathrm{N}$, et al. Risk of maternal mortality in women with severe anaemia during pregnancy and post partum: A multilevel analysis. Lancet Glob Health. 2018;6:e548-54. https://doi. org/10.1016/s2214-109x(18)30078-0.

6. Wuryanti A. Hubungan anemia dalam kehamilan dengan perdarahan postpartum karena atonia uteri di RSUD Wonogiri. ???: ???; 2010.

7. Hasanah W. Anemia Dengan Perdarahan Postpartum Di RSU Dr. Wahidin Sudiro Husodo Mojokerto Tahun 2014. United States: Kti D3 Kebidanan; 2015.

8. Hikmah N, Yani DP. Gambaran hemoragic post partum pada ibu bersalin dengan kejadian anemia di ruang ponek RSUD kabupaten Jombang. Eduhealth 2015;5(2):151. https://doi. org/10.33023/jikeb.v4i1.151

9. Penelitian B, Kesehatan P. Hasil Utama Riskesdas 2018. Jakarta: Kementeri Kesehat Republik Indones; 2018.

10. Baig-Ansari $\mathrm{N}$, Badruddin $\mathrm{SH}$, Karmaliani $\mathrm{R}$, Harris $\mathrm{H}$, Jehan I, Pasha $\mathrm{O}$, et al. Anemia prevalence and risk factors in pregnant women in an urban area of Pakistan. Food Nutr Bull. 2008;29(2):132-9. https://doi. org/10.1177/156482650802900207 PMid: 18693477

11. Abriha A, Yesuf ME, Wassie MM. Prevalence and associated factors of anemia among pregnant women of Mekelle town: A cross sectional study. BMC Res Notes. 2014;7:888. https:// doi.org/10.1186/1756-0500-7-888

PMid:25487251

AQ4 12. Clifford J, Niebaum K, Bellows L. Dietary Fiber. ???: ???; 2015

13. Shah T, Warsi J, Laghari Z. Anemia and its association with parity. Prof Med J. 2020;27:968-72. https://doi.org/10.29309/

\section{tpmj/2020.27.05.3959}

14. Suega K, Dharmayuda TG, Sutarga IM, Bakta IM. Iron-deficiency anemia in pregnant women in Bali, Indonesia: a profile of risk factors and epidemiology. Southeast Asian J Trop Med Public Health. 2002;33(3):604-7.

PMid: 12693598

15. Hurrell R, Egli I. Iron bioavailability and dietary reference values. Am J Clin Nutr 2010;91(5):1461S-7. https://doi.org/10.3945/ ajcn.2010.28674f

PMid:20200263

16. Papadopoulou E, Botton J, Brantsæter AL, Haugen $M$, Alexander J, Meltzer HM, et al. Maternal caffeine intake during pregnancy and childhood growth and overweight: Results from a large Norwegian prospective observational cohort study. Br Med J. 2018;8(3):e018895. https://doi.org/10.1136/ bmjopen-2017-018895

PMid:29685923

17. Wierzejska R, Jarosz M, Stelmachów J, Sawicki J, Siuba M Gestational weight gain by pre-pregnancy BMI. Postępy Nauk Med. 2011;14:718-23

18. Hachul ACL, Boldarine VT, Neto NIP, Moreno MF, Ribeiro EB, do Nascimento $\mathrm{CM}$, et al. Maternal consumption of green tea extract during pregnancy and lactation alters offspring's metabolism in rats. PLoS One. 2018;13(7):e0199969. https:// doi.org/10.1371/journal.pone.0199969

PMid:30020947

19. Van Der Hoeven T, Browne JL, Uiterwaal CS, Van Der Ent CK, Grobbee DE, Dalmeijer GW. Antenatal coffee and tea consumption and the effect on birth outcome and hypertensive pregnancy disorders. PLoS One. 2017;12:e0177619. https:// doi.org/10.1371/journal.pone.0177619

PMid:28520809

20. Błaszczyk-Bębenek E, Piórecka B, Kopytko M, Chadzińska Z, Jagielski $P$, Schlegel-Zawadzka M. Evaluation of caffeine consumption among pregnant women from Southern Poland. Int J Environ Res Public Health. 2018;15(11):2373. https://doi. org/10.3390/ijerph15112373

PMid:30373178

21. Okubo H, Miyake Y, Tanaka K, Sasaki S, Hirota Y. Maternal tota caffeine intake, mainly from Japanese and Chinese tea, during pregnancy was associated with risk of preterm birth: The Osaka maternal and child health study. Nutr Res. 2015;35(4):309-16. https://doi.org/10.1016/j.nutres.2015.02.009 PMid:25773355

22. Huang L, Lerro C, Yang T, Li J, Qiu J, Qiu W, et al. Maternal tea consumption and the risk of preterm delivery in urban China: A birth cohort study. BMC Public Health 2016;16:456. https:// doi.org/10.1186/s12889-016-3100-3

PMid:27246202

23. Widyawati $\mathrm{W}$, Jans $\mathrm{S}$, Utomo $\mathrm{S}$, van Dillen $\mathrm{J}$, Janssen $\mathrm{AL}$. A qualitative study on barriers in the prevention of anaemia during pregnancy in public health centres: Perceptions of Indonesian nurse-midwives. BMC Pregnancy Childbirth. 2015;15:47. https://doi.org/10.1186/s12884-015-0478-3

24. Fan FS. Iron deficiency anemia due to excessive green tea drinking. Clin Case Rep. 2016;4(11):1053-6. https://doi. org/10.1002/ccr3.707

PMid:27830072

25. Wierzejska R. Tea and health-a review of the current state of knowledge. Przegl Epidemiol. 2014;68(3):501-6.

PMid:25391016

26. Ahmad Fuzi SF, Koller D, Bruggraber S, Pereira DI, Dainty JR, Mushtaq S. A 1-h time interval between a meal containing iron and consumption of tea attenuates the inhibitory effects on iron absorption: A controlled trial in a cohort of healthy UK women 
using a stable iron isotope. Am J Clin Nutr. 2017;106(6):141321. https://doi.org/10.3945/ajcn.117.161364 PMid:29046302

27. Lopez A, Cacoub P, Macdougall IC, Peyrin-Biroulet L. Iron deficiency anaemia. Lancet. 2016;387(10021):907-16. https:// doi.org/10.1016/s0140-6736(15)60865-0 PMid:26314490

28. Anggraeni MD, Aji B, Setiyani R, KartikasariA, Rahmawati E. How do modern parents deal with cultural beliefs about breastfeeding? A qualitative study. Br J Midwifery. 2018;26(9):605-13. https:// doi.org/10.12968/bjom.2018.26.9.605

29. Nurdiati DS, Sumarni S, Hakimi M, Winkvist A. Impact of intestinal helminth infection on anemia and iron status during pregnancy: A community based study in Indonesia. Southeast Asian J Trop Med Public Health. 2001;32:14-22.

30. Suryadinata L, Arifin EN, Ananta A. Indonesia's Population: Ethnicity and Religion in a Changing Political Landscape. Singapore: Institute of Southeast Asian Studies; 2003. https:// doi.org/10.1355/9789812305268

31. Israel GD. Determ Sample Size. Florida: University of Florida, Institute of Food and Agricultural Sciences; 2013.

32. Menkes. Profil Kesehatan Tahun 2018 Kabupaten Banyumas. Indonesia: Badan Pusat Statistik; 2019.

33. Polit D, Beck C. Essentials of Nursing Research: Appraising Evidence for Nursing Practice. United States: Lippincott Williams and Wilkins; 2013.

34. Cullis JO. Diagnosis and management of anaemia of chronic disease: Current status. Br J Haematol. 2011;154(3):289-300. https://doi.org/10.1111/j.1365-2141.2011.08741.x PMid:21615381

35. Zhao A, Zhang Y, Li B, Wang P, Li J, Xue Y, et al. Prevalence of anemia and its risk factors among lactating mothers in Myanmar. Am J Trop Med Hyg. 2014;90(5):963-7. https://doi.org/10.4269/ ajtmh.13-0660 PMid:24639302

AQ4 36. Damayanti D. Gizi Dalam Daur Kehidupan. ???: ???; 2019.

AQ5 37. Technology B. User Manual EasyTouch® GCHb; 2010.

38. World Health Organization. Haemoglobin Concentrations for the Diagnosis of Anaemia and Assessment of Severity. Geneva: World Health Organization; 2011.

39. World Health Organization. Nutrition: Exclusive Breastfeeding. Geneva: World Health Organization; 2011. Available from: http://wwwWholnt.

40. Bhargava A, Bouis HE, Scrimshaw NS. Dietary intakes and socioeconomic factors are associated with the hemoglobin concentration of Bangladeshi women. J Nutr. 2001;131(3):75864. https://doi.org/10.1093/jn/131.3.758 PMid:11238756

41. Triharini M, Armini NK. Family functioning, intention, and adherence to iron supplementation among pregnant women in Surabaya, Indonesia. Eur J Biosci. 2020;14:6841-7.
42. World Health Organization. World Health Statistics 2015. Geneva: World Health Organization; 2015.

43. Brabin BJ, Hakimi M, Pelletier D. An analysis of anemia and pregnancy-related maternal mortality. J Nutr. 2001;131(2):604S15. https://doi.org/10.1093/jn/131.2.604s PMid:11160593

44. Hidayah W, Anasari T. Hubungan kepatuhan ibu hamil mengkonsumsi tablet fe dengan kejadian anemia di Desa Pageraji Kecamatan Cilongok Kabupaten Banyumas. Bidan Prada J Publ Kebidanan Akbid YLPP Purwokerto. 2012;3(2):322. https://doi.org/10.35872/jurkeb.v9i02.322

45. Nik Rosmawati NH, Mohd Nazri S, Mohd Ismail I. The rate and risk factors for anemia among pregnant mothers in Jerteh Terengganu, Malaysia. J Community Med Heal Educ. 2012;2:711-2161. https://doi.org/10.4172/2161-0711.1000150

46. HealthLink BC. Iron in Food. Columbia: HealthLink BC; 2017.

47. Fauziyyah RL. Pengaruh konsumsi hati ayam terhadap kadar hemoglobin pada ibu hamil trimester ii di puskesmas Ngoresan. Placentum J Kesehat Dan Apl. 2016;4:1-9. https:// doi.org/10.37341/interest.v5i2.58

48. Imai E, Nakade M. Fish and meat intakes and prevalence of anemia among the Japanese elderly. Asia Pac J Clin Nutr. 2019;28(2):276.

PMid:31192557

49. Nurdiman M, Ramadhany A. Statistik Peternakan dan Kesehatan Hewan. Jakarta: Direktorat Jenderal Peternakan dan Kesehatan Hewan, Kementrian Pertanian Rl; 2018. https:// doi.org/10.19087/jveteriner.2015.16.4.474

50. Darmawati D. Faktor sosial ekonomi, pola makan dan prevalensi anemia defisiensi zat besi pada ibu hamil. J IIm Mhs Fak Keperawatan. 2019;4:216. https://doi.org/10.33746/fhj. v7i02.148

51. BPOM. Penjelasan BPOM RI Tentang Susu Kental Manis (SKM). https://doi.org/10.25134/ijsm.v1i2.1387

52. Quartz. Annual Per Capita Tea Consumption Worldwide as of 2016, by Leading Countries (in Pounds). United States: StatStat Portal 2018.

53. Ward S, Hisley S, Kenndey AM. Maternal-child Nursing Care: Optimizing Outcomes for Mothers, Children, and Families. Philadelphia, PA: F.A. Davis Company; 2009.

54. Lebso M, Anato A, Loha E. Prevalence of anemia and associated factors among pregnant women in Southern Ethiopia: A community based cross-sectional study. PLoS One. 2017;12(12):e0188783. https://doi.org/10.1371/journal. pone. 0188783

PMid:29228009

55. Noviyanti B, Simanjuntak HC, Hutasoit ES, Silitonga HA, Julianto $\mathrm{E}$. The Relationship between social economic levels and anemia events in pregnant women in Glugur Darat health center. J Matern Child Health. 2019;4:440-7. https://doi. org/10.26911/thejmch.2019.04.06.05 